\title{
For a Holistic View of Biotechnology in West and Central Africa: What Can Integrated Development Approaches Contribute?
}

\author{
Francis Rosillon \\ University of Liège, Water, Environment, Development Unit, Arlon Campus, Arlon, Belgium. \\ Email: f.rosillon@ulg.ac.be
}

Received March 21 ${ }^{\text {st }}$ 2013; revised April 23 ${ }^{\text {rd }}, 2013$; accepted May $16^{\text {th }}, 2013$

Copyright (C) 2013 Francis Rosillon. This is an open access article distributed under the Creative Commons Attribution License, which permits unrestricted use, distribution, and reproduction in any medium, provided the original work is properly cited.

\begin{abstract}
Africa, ever on the lookout for development levers that will allow its economy to take off, is turning more and more towards technology. This is one of the possible modern avenues to success, especially the use of the biotechnologies that are so touted by Western countries. However, the hope placed in these new technologies must not hide the longproven fact that technology alone is not enough to solve development problems. Biotechnologies do not escape this rule. Biotechnologies can be the best and the worst things for the people of Africa. Beyond their technical contributions, we must be wary of their boomerang effects and collateral damage. A country's development is actually more complex than simply implementing technology, and in the current global environmental context a holistic vision is necessary to ensure sustainable development. In the area of water, this integrated vision emerged on the international scene during the Dublin Conference in 1992, which consecrated the principles of Integrated Water Resources Management (IWRM). More recently, the Eco-Health concept strives to combine human health and ecosystem health while incorporating a socioeconomic dimension into the health and environmental spheres. The concern to mesh human activities better with environmental protection was materialized previously, in the 1970s already, through impact studies. After presenting this set of tools in the service of a holistic approach to the environment and development, we shall see that these approaches can inspire the players when it comes to the ways they implement biotechnologies. At the end of the day, a holistic approach to biotechnologies in Africa will be facilitated by enhanced information and communication and reliance on peasant farmers' expertise. It will have to be rooted in broader participation of the players concerned. This integration will also concern environmental and land-owning aspects, without forgetting socio-cultural acceptance of the projects and the links with health. Ultimately, it will also mean putting the human at the heart of development by taking all the richness and particularities of African society into account.
\end{abstract}

Keywords: Biotechnology; Africa; Development; Integration; Holistic Approach

\section{Introduction}

Africa, ever on the lookout for the levers of development that will get its economy to take off, is turning more and more towards technology. It is one of the possible modern avenues, especially that of biotechnology, which is so touted by Western countries. The Economic Community of West African States (ECOWAS) has held a spate of conferences and meetings on the subject, e.g., in Dakar in 2004, Ouagadougou in 2004, Bamako in 2005, Accra in 2007, and so on. However, the hope placed in these new technologies must not hide the fact that it has long been known that technology alone is not enough to solve development problems. Biotechnology is no exception.
Biotechnologies can be the best and the worst things for the people of Africa. However, beyond their purely technical contributions, we should be wary of their boomerang effects and collateral damage.

Biotechnology is sometimes presented as the "new means of the new green revolution that will usher humankind into a new era of abundance” (Pallante, 2011) [1], with reference to the green revolution that stroves to increase agricultural yields through the use of fertilizers and pesticides. However, according to an International Labor Organization (ILO) report quoted by Pallante (2011), "hunger and malnutrition are increasing very quickly, especially where the green revolution occurred” 
[1]. Let us hope that the same will not happen with the application of agricultural biotechnologies.

Developing a country is actually more complex than simply applying techniques and, given the current global environmental context, a holistic vision is necessary to achieve sustainable development. Let us recall that the neologism "holism" is coined in 1926 and comes from the ancient Greek holos meaning "the whole, the entirety." It was proposed by the South African statesman Jan Christiaan Smuts in his book "Holism and Evolution". According to Smuts, holism is the tendency in nature to form wholes that are greater than the sum of their parts through what he calls "creative evolution". It is thus the opposite of narrow, sectorial approaches, but it aims to integrate the various interacting components within a complex system.

While various integrating concepts of development existed, that of sustainable development, which was inherited from the Brundtland report and spread during the Rio Conference in 1992, conquered the entire planet. However, well before then, in the early 1970s, the desire to mesh human activities better with environmental protection had already materialized in the form of environmental impact studies. The integrated, holistic view emerged on the international water management scene during the Dublin Conference of 1992, which consecrated the principles of Integrated Water Resources Management (IWRM). More recently, the Eco-Health concept is aimed at combining human health and ecosystems' health while integrating a socioeconomic dimension into the health-environment sphere.

The complex and multifold nature of biotechnologies calls for this type of integrated approach. After reviewing biotechnology's complexity, we shall recall the series of integrating concepts mentioned above. We shall also see how these approaches, which make it possible to go from a sectorial approach to a holistic vision of development, can inspire the biotechnology players in implementing their biotechnology choices. The idea will also be to put the human at the heart of development processes by taking all the richness and particularities of African society into account. However, much uncertainty exists about the consequences of implementing biotechnologies on human and environmental health and the economy of a country. We shall thus try to show here the advantages of taking a holistic approach as far upstream as possible from the projects concerned, an approach that considers the environmental, societal, economic, and other externalities, so as to circumscribe this uncertainty as best one can.

\section{Biotechnologies at the Intersection of Several Fields}

The term "biotechnology" already contains a binomial in which two different worlds meet, namely, the world of living things and the world of production processes. The word is often used in the plural, adding an additional layer that refers to the diversity of processes developed. The Organization for Economic Cooperation and Development (OECD) defines biotechnologies as "the application of scientific principles and engineering to the transformation of materials by biological agents to produce goods and services.” The term can also be broken down into the following three elements: bio for life, techno for the tools that are developed, and logis for mastery of the process. This adds up to biotechnology for mastering the tools of the living. The various types of biotechnology also take on different colors: the green biotechnology of agricultural value, red biotechnology of medical value, and white biotechnology, which EuropaBio defined in 2003 as the application of natural processes to industrial production, especially that of biological engineering in the service of chemistry. Biotechnologies are thus situated at the crossroads of three areas of expertise: health, agrifood, and the environment.

According to the West and Central African Council for Agricultural Research and Development (WECARD), biotechnologies are taking root in the world market, with a turnover of $\$ 9.2$ billion in 2009. They account for more than $40 \%$ of the seed market and $30 \%$ of the pesticide market, while 14 million peasant farmers use them [2]. The developing countries do not want to be excluded from this new market.

The developing countries, especially those in SubSaharan Africa, are thus placing great hope in biotechnology as a way to solve the problems of hunger and poverty in particular. So, according to A. Traoré (2005), the strategic choice of promoting the planting of transgenic Bt (Bacillus turingensis) cotton should be a powerful way to fight poverty [3]. According to Jacques Diouf, director of the UN's Food and Agriculture Organization (FAO), as quoted by A. Traoré (2005), "It is now widely recognized that we have entered a post-Green Revolution era and conventional selection has reached a ceiling in terms of crop yields. Biotechnologies and genetic engineering should be able to help solve this problem by increasing yields significantly".

A Sahel and West Africa Club (SWAC) secretariat consultation of the players concerned by the introduction of biotechnologies showed the many advantages that the spread of these biotechnologies were expected to have in Africa. However, caution is still necessary, as shown by the consultation report's chapter on perceptions of the risks that can be linked to the use of biotechnologies and are feared by farmers and civil society organizations [4]. These concerns belong to a variety of spheres, namely,

- the socioeconomic sphere; 
- regulatory, political, and strategic constraints;

- the environment;

- human health;

- and ethical considerations.

The diversity of fields affected by biotechnologies thus gives us cause to envision their implementation within an integrated approach. Concepts and tools exist to frame the integrated development of these biotechnologies.

\section{A Few Integrating Concepts in the Service of African Biotechnologies}

\subsection{The Sustainable Development Concept}

The various spheres listed above recall the multidimensionality of sustainable development, which can be applied to biotechnology so as to meet the people's needs without jeopardizing those of future generations. Sustainable development's multidimensionality is actually a reflection of all the complexity that characterizes the human being and society alike. As Edgard Morin pointed out in 1999, the human being is biological, mental, social, emotional, and rational all at the same time, while society contains historical, sociological, economic, religious, and ethical dimensions [5]. Sustainable development does not escape this fundamental complexity, which is traditionally situated at the intersection of three main fields (ethics, economics, and the environment) and crisscrossed by anthropocentric or ecocentric currents.

In the years after the Rio Conference, and even today, implementing sustainable development in actual fact was fraught with many difficulties. One such difficulty was a lack of criteria or characteristics to help guide the players' strategic choices and use of appropriate management tools guaranteeing that all these characteristics are taken into account. So, as part of a research program on sustainable development and water we compiled a list of criteria in order to judge whether the strategy adopted strayed from or was close to the concept of sustainable development (Table 1) [6].

The criteria proposed above can be used as a grid for analyzing all development projects, including biotechnology development projects. However, besides this chief notion of sustainable development, other, more hands-on, approaches, such as impact assessments, can also be mobilized.

\subsection{Impact Assessments}

Environmental and social impact assessments are part of the project evaluation processes that donors and international bodies already require. The aim is to estimate and predict the consequences of a development action on the environment and society. The assessment can concern projects, policies, technologies, and consumption choices
Table 1. A few sustainable development criteria (from Rosillon, 2011).

\author{
A few sustainable development criteria \\ Social criteria \\ Agreement on a philosophy and an outlook \\ Guaranteeing democratic operation \\ Taking all needs into account \\ Promoting inter- and intra-generational management \\ Acting on the long term \\ Promoting education and training \\ Environmental criteria \\ Overall ecosystemic approach \\ Good knowledge of the problems and things \\ at stake, along with reliance on expertise \\ Heeding the biogeochemical cycles \\ Heeding ecosystems' carrying capacities \\ Promoting socio-cultural and biological diversity \\ Incorporating environmental policies \\ Precautionary principle \\ Principle of prevention \\ Economic criteria \\ Economic efficiency \\ Productivity of the resource \\ The "polluter pays" principle \\ Sustainable financing \\ Asset management
}

[7]. The idea is to analyze their effects on the environment and society, measure their degree of acceptability, propose remedial actions, and provide assistance in deciding whether or not developing a project is opportune. This is an interdisciplinary process that also pulls in the local population by making the study -as a rule supplemented by a non-technical summary for the public at large-available and organizing information sessions to ensure the project's transparency.

Allusions to impact assessments can already be found in Burkina Faso's legislation in 1977. Article 17 of law 0052/97/ADP of January 30, 1977, concerning the Environment Code of Burkina Faso stipulates, “....activities likely to have significant impacts on the environment are subject to the Environment Minister's prior opinion. This opinion is made on the basis of an environmental impact assessment or notice." This provision was confirmed 
more recently by law 005/97/ADP of January 30, 1997, concerning the Environment Code of Burkina Faso. This text refers to the environmental impact assessment (EIA) and environmental impact notice (EIN) as tools for incorporating environmental concerns in development projects and plans.

While these impact studies are excellent integrating tools, they sometimes come up against a lack of data and quantifiable indicators in the countries of the South. Consequently, it is necessary to bolster expertise regarding the generation of knowledge allowing the best possible characterization of the project and its possible impacts on the environment and health. Shouldn't this expertise cover the development of assessment methods that are particularly suitable for biotechnologies while including the notion of time as well, since it can take a very long time for these impacts to arise?

\subsection{Integrated Water Resources Management (IWRM)}

After this succinct presentation of two generalist approaches to integration, let us examine the IWRM concept regarding the water sector.

Water management-basically access to water and drainage systems - was long considered to be mainly a technical problem. Thousands of miles of pipes were laid down by hydraulic engineers around the world to convey water to the places where it was needed or remove it where it was bothersome. Catchment works, dams, manmade reservoirs, hydroelectric power plants, and drainage works were built and are still being built today [8]. However, this technical approach overlooked the fact that water had many facets beyond being the simple molecule " $\mathrm{H}_{2} \mathrm{O}$ ". Today, water is the subject of a wide range of interests expressed by numerous users. Finally, all the inhabitants of the planet feel concerned by this familiar asset that is indispensable for life. Along with its technical dimension, water thus has various other dimensions: environmental, social, economic, legal, educational, cultural, and spiritual.

The definition of IWRM, which was historically attached to the four principles set during the International Conference on Water and the Environment in Dublin in 1992, was clarified later on. The definition given by the Global Water Partnership (GWP) is regularly quoted, to wit, "Integrated Water Resources Management is a process which promotes the coordinated development and management of water, land and related resources in order to maximise economic and social welfare in an equitable manner without compromising the sustainability of vital ecosystems and the environment”. IWRM thus takes water resources' dynamics in the natural areas of watersheds and aquifers into account, with all of the players in the water sector being involved in a new management framework that strikes the best balance among all of water's uses.

However, what does integration mean in the field of water? The term "integration" meets the following two definitions [8]:

1) Integration of an element in a larger set:

- integration in the hydrosphere and the global water cycle;

- integration in the development concepts or programs that are deemed important and/or priorities (sustainable development and climate change, for example).

2) Integration of the parts with each other:

- integration of all resources: water in all its forms, quantitative and qualitative resources, an ecosystemic approach that respects the ecosystem's integrity, the quality of aquatic environments, which results from three components (physical, chemical, and biological), regenerative potentials, and ecosystems' carrying capacities versus users' ecological footprints;

- integration of knowledge and expertise;

- social integration: integration of needs and functions and harmonization of uses;

- integration of the players: participation and policy integration;

- economic integration; and

- spatial integration: the catchment area.

In actual practice, this integration, which is so strongly desired, still often finds itself hobbled by strong sectorial management patterns, while in developing countries IWRM is hemmed in by organizational and socio-cultural barriers [9]. Yet IWRM is characterized by a holistic, crosscutting, multidisciplinary approach that can also be applied in the field of biotechnology.

\subsection{Eco-Health: Human Health and Ecosystems' Health}

Here is another example of an integrating concept, this time in the field of health. Like the concept of sustainable development, the Eco-Health approach puts health at the intersection of environmental, economic, and social factors. This concept is widely defended by the International Development Research Centre (IDRC), a Canadian state entity that puts its faith in researchers from the South to solve their countries' development problems. According to Jean Lebel (2003), no less than human beings' places in their environment are riding on the ecosystemic approach to human health [10].

The ecosystemic approach thus gives as much importance to good environmental management as to economic factors and the community's aspirations when it comes to resource management [10]. An Eco-Health approach also takes care to get the local communities directly involved 
in research programs and initiatives that are implemented with them in mind. It does so through monitoring committees that supervise the process and in which representatives of users and civil society take part.

It is thus necessary to go beyond the purely health and environmental perspectives in order to solve, with all the players, the sources of environmental degradation that affect health. The Eco Health approach aims both to improve human beings' health but also to enable ecosystems to function well so that they can carry out their natural functions in terms of maintaining biodiversity and potential resources.

This holistic approach can also be a way to combat poverty, which can be translated as a lack of satisfactory responses to all human beings' vital needs, i.e., access to resources (water, food, energy, etc.), the availability of a safe living space, accommodations, and so on. However, poverty also drives the poor to take risks to survive. This is how Kofi Annan, then Secretary-General of the UN, put it in 1999: “...poverty and demographic pressure are driving more and more poor people to live exposed to danger, on plains that are subject to flooding, in areas exposed to earthquakes and on unstable hillsides". (Kofi Annan, 1999, in USAID, 2006) [11].

The situation of a degraded environment and chronic poverty is often compounded by bad governance. Here we have all the macabre elements of the vicious circle of human and environmental distress (Figure 1) [12].

Human health results from environmental conditions and chronic poverty, but also from problems of organization and governance in the country. The main challenge that must be taken in poor countries is to break the vicious circle that is maintained by sectorial approaches and inappropriate policy choices, be they national initiatives or imposed on the country by international bodies.

We have dared to draw a parallel between the EcoHealth approach and biotechnologies, since the latter are also mentioned as providing possible ways to fight poverty in Sub-Saharan Africa [3]. Will biotechnologies be

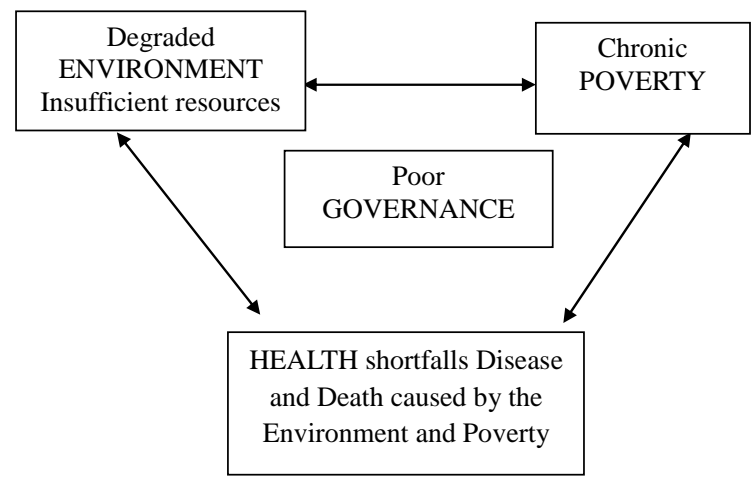

Figure 1. The vicious circle of human and environmental distress [12]. able to break this vicious circle of human and environmental distress, or do we run the risk of causing a shift to other forms of environmental and social degradations, health problems, and a new type of poverty?

\section{Some Elements for the Integrated Development of Biotechnologies in West and Central Africa}

What can we take from these integrated approaches when we look at the implementation of biotechnologies in West and Central Africa? Below we have set out a few of the elements that can be taken into account in favor of a holistic vision of biotechnologies, especially in the area of agriculture, based on the four concepts outlined previously. This list is far from exhaustive.

\subsection{Information and Communication}

The information and communication duo is definitely one of the conditions for integrated development. In the field of biotechnologies, various voices have been raised to denounce the all-too-frequent absence of an impartial information and communication policy, especially when it comes to genetically modified organisms, which trigger fear of the unknown and open the door to all sorts of misunderstandings and assumptions [4]. One cannot content oneself with the unilateral information provided by seed-producing multinationals. Cross-examination of the subject and confrontational debate must be accepted. Before anything else, it appears to be vital that the information circulate among the players directly involved but also to the public at large. The biotechnology firms and researchers brought together by the IDRC in Ouagadougou in November 2004, it should be added, voiced the need to develop a public information system on biotechnology [4].

To trigger a broad democratic countrywide debate, might it not be opportune to organize a national biotechnology conference? The Academy of Science and Technology of Senegal (ASTS) had already proposed a national conference for Senegal in 2004 [13]. This would be an opportunity to launch a broad information campaign on the subject and promote initiatives to explain biotechnologies to the public at large in a language that they can understand while offering an area for exchange and debate on the issue. Care would be taken to let minorities and modest peasants, who are sometimes sidelined or exploited by the new biotechnology bosses, have their say. This conference could also be the crucible in which the policy line to follow in this area could be cast. It could also be a forum for drawing up an appropriate legal framework in which the general conditions of development and implementation, property rights, envi- 
ronmental and health responsibilities, bio-safety, inspection and monitoring schemes, and so on could be spelled out in a manner that would avoid a "cut-and-paste" of Western models and, on the contrary, specify what is good for West and Central Africa.

\subsection{Participation}

However, informing, even consulting, the people on this topic could also lead to a more intense form of participation. Indeed, when it examined the prospects for implementing biotechnologies in Africa, the ASTS (2004) called for the participation of all the entities involved and the setting of a determined strategy [13]. What is more, the West African Network Farmers' and Producers' Organizations and the West African Network Chambers of Agriculture demanded, back in 2005, "the institution of broad debates in the population in order to enable them to participate in the decision-making" up to and including an at least five-year moratorium in the Economic Community of West African States (ECOWAS) area to give the people time to be informed and participate in making the decision to go with biotechnologies or not [14]. More recently, the FAO made a case for having small farmers participate more in decisions regarding biotechnologies during the Guadalajara Conference in Mexico in 2010 [15].

This participation could also be materialized by the creation of a national biotechnology council as an independent biotechnology development watchdog or observatory. Locally, on the project level, a community steering committee assembling the main forces of the communities concerned might also be created.

\subsection{Territorial Integration and the Land}

The aim of an important biotechnological subset is to increase crop yields by using genetically improved seeds to replace other plant varieties. As arable land is not infinite, might not certain projects run the risk of being seen as competing with traditional crops? For example, there are possible conflicts of land use between subsistence crops and major cash crops for export, or between local food crops and new crops for biofuel production.

In all cases, land is the object of increasingly stiff competition among various players and not just rural inhabitants. Small farmers, indigenous peoples, immigrants, the private sector, development projects, agribusiness, and other groups have all entered the fray. In developing countries the problem of land use is often complex and divided among a large number of players governed by either customary or modern law.

So, we see a layer cake of land use rights over, even title to, the same area. According to Le Roy et al. (1996), quoted in Rosillon \& Bado-Sama (2008), the surface area gives rise to a right of access and the resource to a right of harvesting, operation, or possession [16]. However, let's not forget that an area's value is contingent on the resources that it harbors or is likely to contain (Weler, 1998, in Rosillon \& Bado-Sama, 2008) [16]. Biotechnologies generate new resources that must thus find their places in the available area, but integrated development cannot ignore the land ownership issues mentioned above.

\subsection{Environmental Integration}

The ecosystemic approach is used to take all of the biophysical environment's compartments, i.e., the ground, air, water, biodiversity, and energy, into account. It is also necessary to examine the effects that are produced locally, in the sub-region, and even internationally, both in the short and longer term, and even in the very long term. The saying "Act locally, think globally" will also apply. Externalities and side or collateral effects absolutely must be taken into account. (Example: Using smaller amounts of pesticides improves the quality of the environment and reduces the production costs linked to purchasing such inputs, but are the treated plants more vulnerable to other parasites not covered by the genes of resistance that have been incorporated in the new seeds' DNA, and what will the effects on health and biodiversity be?) Preserving biodiversity will thus be vital, and there is the risk of "genetic contamination by transfer of the modified genes to local primary strains" that can lead to "a disorganization of the ecosystem and, ultimately, the disappearance of the local genetic heritage" [4].

The new products' whole life cycles and overall ecological footprints both upstream (in the research and development phases) and downstream (in the production, consumption, and elimination phases) must be analyzed. This means factoring in all the indirect costs and environmental and social externalities.

\subsection{Health and Biotechnologies}

What are the links between human health and biotechnological food production? The problem is complex. What are the links between the resurgence of cancers and GMOs? What are the links between cases of allergies and the consumption of GMOs? What about the development of resistance to antibiotics, the production by transgenic plants of toxins that are harmful to human health [4]? All these questions have yet to be answered.

Today, as Professor Séralini's team (2012) is disseminating the results of their research on the impact of GMOs on rats fed Round Up-tolerant transgenic corn, the debate about using these GMOs correctly has been re- 
opened. According to their studies, rats fed for two years with transgenic NK 603 corn and non-genetically engineered corn treated with Round Up died earlier than their fellow rats fed with untreated corn. The rats in the first two groups developed kidney, liver, and breast tumors, revealing the herbicide's long-term chronic toxicity [17]. However, Séralini's research has been criticized for a lack of scientific method and refuted by France's High Council of Biotechnologies [18] and the National Food Safety Agency [19]. The seeds of doubt have been planted and the international scientific community is split, reflecting once again all the complexity that surrounds the use of biotechnologies.

We are operating in an increasingly complex world in which yesterday's truths are challenged and swell the ranks of our uncertainties and doubts. The wake-up call, when it comes, will be all the more of a shock if we develop policies and projects sectorally, by looking at only a small part of the problem, without imagining the consequences of a policy or project on elements that are sometimes very remote from the subject. Given these uncertainties, shouldn't we give priority to the precautionary principle inherited from the foundation of sustainable development? And shouldn't the health field be tackled using the previously described Eco-Health approach?

\subsection{Socio-Cultural Acceptance}

While technology alone cannot solve the problems of development, it nevertheless must first be accepted by society and taken up by the populations that are concerned.

Today's biotechnologies come for the most part from research programs carried out in Western countries. It is very often a matter of exporting technologies to developing countries in contexts that are very different from those in which they arose. According to Pallante (2011), simply adjusting production patterns to territories, knowhow, and forms of social organization must be avoided. He continues by mentioning the risks of agro-industrial excesses: “...getting people to grow exportable commodities by supplying the seeds and inputs, complete with user's manual, and after the harvest shipping the products to the West, steps that the small farmer has no control over, so that he is dependent on the global economy and its fluctuations" [1].

Leading-edge biotechnologies for cash crops are not sustainable in the long run if the rural populations are excluded, with the risk of creating a social divide affecting the most vulnerable family farmers, and if poverty is not overcome. The idea is not to eradicate subsistence farming in favor of agro-industry. On the contrary, agribusiness must leave room for crop diversity, local mar- keting and processing of harvests, and respect for the peasants' loyalty to their own culture, while guaranteeing their self-sufficiency and independence [1]. Finally, sociocultural acceptance of biotechnologies will also entail the peasants' freely given acceptance of changes in production patterns regarding the fact, for example, that farmers will no longer be able to harvest their own seeds.

So, we must bear in mind that genetically modified crops can also run aground on religious and cultural sand bars, for example, due to new varieties' potential impacts on traditional seed systems [20] or the destruction of inter-specific barriers between species, especially given the matter of gene mobility between the animal and plant kingdoms [4].

\subsection{Integration of Local Expertise}

Even if the development of biotechnologies calls for high-level human skills and high-tech material means of research, with the creation of centers of excellence and research clusters in particular, local expertise must not be overlooked. That is the message that François Traoré (2006) wanted to put across in his acceptance speech of the title of Doctor honoris causa from the Agricultural College of Gembloux (Belgium) [21]. To avoid these new technologies' being perceived as "impositions from on high," farmers must be involved in the processes of developing new varieties [20].

In fact, when it comes to intellectual property rights, the FAO proposes recognizing the rights of farmers as the holders of local genetic assets within the International Union for the Protection of New Plant Varieties [4].

\subsection{New rules for the World Market}

According to an OECD report from 2009, “....between now and 2015 around half of global production of the major food and feed crops will probably come from plant varieties developed with the help of biotechnology" and by 2030 biotechnology could contribute up to $2.7 \%$ of gross domestic product (GDP) in industrialized countries and even more in developing countries, given that the latter's economies are more heavily dependent on agriculture [22]. Moreover, the European Union is investing 1.9 billion euros in the creation of a European bioeconomy under the banner of "food, agriculture, fisheries, and biotechnology" as part of the $7^{\text {th }} \mathrm{R} \& \mathrm{D}$ Framework Program (FP7) [22].

The economic stakes riding on biotechnology are thus enormous, but for developing countries the problem is to cope with the new masters of biotechnologies without locking themselves into new relationships of dependence on Western countries and the seed-producing multinationals that are taking up monopoly positions on the 
global market. Even more crucially, how can food sovereignty be guaranteed if the countries have no control over the production and distribution of the seeds that are used?

From a global standpoint, we can also wonder how Africa is going to position itself in the geopolitics of biotechnology, caught as it is between the US-EU pincers' jaws and given Asia and Latin America's increasing power [23]. Rather than having each country react individually to developments, the African position should be strengthened if the countries of West and Central Africa band together and pool their capacities, expertise, and experience while making sure that the countries coordinate their policies.

\section{Conclusions}

It is understandable that Africa does not want to miss out on this new biotechnology market in which the countries of the North dominate. There is even the feeling that biotechnologies are the door through which the countries of Sub-Saharan Africa will enter globalization [13]. However, these techniques and technologies can also engender new types of dependence, notably on the seed suppliers' monopolies, for these multinationals are flooding the market with their selected seeds, against which the peasants' seeds have little say. It will also be necessary to oversee the spread of biotechnologies in Africa through new regulatory frameworks that spell out the rules of biosafety, intellectual property, and patentability, among other things, while safeguarding local interests.

To claim to benefit from the fallout of these biotechnologies as levers of development, the countries of West and Central Africa's scientific and technological lag will have to be overcome by bolstering their capacities and stepping up collaboration between research teams from the North and the South. Along with WECARD [2], we think that technical and financial means will have to be freed up for researchers in developing countries. However, this expertise will have to take specifically African environmental and socio-cultural aspects into account as well.

It is also a good idea for the African development model to differentiate itself from Western models by taking a holistic approach that puts the human back at the heart of the debate and factors in all aspects of life in society. Great pains must be taken not to dissect the living and pick out the favorable elements that could lead to more profitable production and consumption processes. Without wanting to teach anyone a lesson, this plea for a holistic approach to biotechnology has recalled a few integrating concepts that the African biotechnology strategy could mobilize.

A vast field of research and adaptation is opening up to turn biotechnologies into a genuine lever of human development in which all the peoples of Africa will come out winners. Many types of ability will be required, and besides engineers, multidisciplinary teams of environmentalists, doctors, sociologists, etc., and local farmers' representatives will have to be set up in order to grasp all of biotechnology's intrinsic complexity. This broadening of competences will be facilitated by the creation of forums for dialog and knowledge sharing along the lines of the regional colloquium organized by Ouagadougou University in November 2012 [24].

May biotechnologies help to break the vicious circle of poverty by bolstering food self-sufficiency and improving human and environmental health in West and Central Africa!

\section{REFERENCES}

[1] M. Pallante, "La Décroissance Heureuse, la Qualité de vie ne Dépend pas du PIB,” Nature et Progrès, Namur, 2011, p. 222.

[2] D. Zarour Medang, "West Africa: The Biotechnology at the Heart of the Development, WECARD Makes the Plea," 2010.

http://fr.allafrica.com/stories/printable/201012220555.html

[3] A. Traoré, "La Biotechnologie, un Outil Efficace Dans la Lutte Contre la Faim et la Pauvreté en Afrique Subsaharienne: Cas du Burkina Faso,” Actes Maîtrise des Procédés en vue d'améliorer la Qualité et la Sécurité des Aliments, 8-11 November 2005, Ouagadougou, p. 8.

[4] J. S. Zoundi, L. Hitimana and K. Hussein, “Agricultural Biotechnology and the Transformation of West African Agriculture: Synthesis of the Regional Consultation with African Actors," Sahel and West Africa Club Secretariat (SWAC/OECD), 2006, p. 27.

[5] E. Morin, "Les Sept Savoirs Nécessaires à l'éducation du Futur,” Ecole Nationale Supérieure des Mines, Saint-Etienne, 1999. http://www.agora21.org/menu.html

[6] F. Rosillon, “Gestion Participative de L'eau et Développement Durable, Application à la Gestion de L'eau en Région Wallonne à travers L'expérience des Contrats de Rivière,” Editions Universitaires Européennes, Saarbrücken, 2011, p. 360.

[7] M. Tchindjang, "Les Études D’impacts Environnementaux,” University of Yaoundé 1, Yaoundé, 2009. http://web.cm.refer.org/eie/chapitre2_1.html\#2.1.1

[8] F. Rosillon, "La GIRE Décryptée, Éléments Pour un Renforcement de la GIRE en Haïti et Dans les Pays en Développement,” PROTOS-ULG, 2010, p. 144.

[9] F. Rosillon, "Quelques clés de Succès et Verrous Pour des Portes Résistantes à la GIRE,” Revue Liaison Energie-Francophonie, Vol. 92, 2012, pp. 16-21.

[10] J. Lebel, “La Santé: Une Approche Écosystémique,” IDRC, Ottawa, 2003, p. 84.

[11] USAID, "Vulnérabilité Environnementale en Haïti," 
USAID, Haiti, 2006, p. 146.

[12] F. Rosillon, "La Gestion Intégrée de L’eau en Haïti, Levier de Santé Environnementale et Humaine,” In: E. Emmanuel, et al., Eds., Santé Humaine et Équilibre Biologique des Écosystèmes à Port-au-Prince: Analyse et gestion des Risques Urbains et Environnementaux, Quisqueya University, accepted 2013, p. 38.

[13] Academy of Science and Technologies of Senegal (AS TS), “The Biotechnologies, the Potential, the Stakes and the Perspectives: The Case of the Senegal," ASTS Report, Dakar, 2004.

[14] S. Traoré, "Produire Plus, Sans Mettre en Danger L’homme et Son Environnement?" Initiatives, Grain de sel No 32, 2005, pp. 29-30.

[15] FAO, "Biotechnologies Should Benefit Poor Farmers in Poor Countries, Mexico Conference Takes Stock of Conventional Biotechnology Applications in Food and Agriculture,” 2010.

http://www.fao.org/news/story/en/itm/40390/icode/

[16] F. Rosillon and H. Bado-Sama, "Contribution à la Gestion Intégrée des Eaux et des Sols à Travers L’application du Contrat de Rivière Sourou au Burkina Faso," Proceedings of Journées Scientifiques du Réseau de Chercheurs en Développement Durable de L'AUF, IRD-AUF, Hanoï, 2008, p. 12.

[17] G.-E. Séralini, E. Clair, R. Mesnage, S. Gress, N. Defarge, M. Malatesta, D. Hennequin and J. Spiroux de Vendômois, "Long Term Toxicity of a Roundup Herbicide and a Roundup-Tolerant Genetically Modified Maize," Food and Chemical Toxicology, Vol. 50, No. 11, 2012, pp. 4221-4231. doi:10.1016/j.fct.2012.08.005

[18] Haut Conseil des Biotechnologies, “Avis en Réponse à la Saisine du 24 Septembre 2012 Relative à L'article de Séralini et al. (Food and Chemical Toxicology, 2012),”
Comité Scientifique, 2012, p. 37.

http://www.hautconseildesbiotechnologies.fr

[19] ANSES, “Avis de l’Agence Nationale de Sécurité Sanitaire de L'alimentation, de L'environnement et du Travail Relatif à L'analyse de L'étude de Séralini et al. (2012), Long Term Toxicity of a ROUNDUP Herbicide and a ROUNDUP-Tolerant Genetically Modified Maize,” 2012, p. 51. http://www.anses.fr/Documents/BIOT2012sa0227.pdf

[20] O. Ezezika and J. Mabeya, “Comment Collaborer Avec les Agriculteurs sur les Cultures GM?” Le Réseau Sciences et Développement, 2012, http://www.scidev.net/fr/agriculture-and-environment/

[21] F. Traoré, "Les Chroniques de François Traoré: La Crise du Coton Vue par un Agriculteur Burkinabé,” Biotechnology, Agronomy, Society and Environment, Vol. 10, No. 4, 2006, pp. 295-297. http://popups.ulg.ac.be/Base/document.php?id=536

[22] CORDIS, “OECD Sets Out Opportunities and Challenges for Future Bioeconomy,” 2009. http://cordis.europa.eu/fetch?CALLER=EN_NEWS_FP7 $\& A C T I O N=D \& D O C=3 \& C A T=N E W S \& Q U E R Y=013 d 3$ 21c507d:b165:23801e16\&RCN=30881

[23] T. Raffin, "Les Plantes Génétiquement Modifiées dans les PVD: Entre Discours et Réalité,” Revue Tiers Monde, ND, pp. 705-720.

http://www.cairn.info/article_p.php?ID_ARTICLE=RTM _188_0705

[24] CRSBAN, University of Ouagadougou, "The Biotechnologies in Front of Challenges of the Sustainable Development in West and Central Africa," Center of Research in Biological Sciences Food and Nutritional, CRSBAN, 2012, p. 60. 